\title{
Potential correlates of burnout among general practitioners and residents in Hungary: the significant role of gender, age, dependant care and experience
}

\author{
Szilvia Adam¹, Andras Mohos², Laszlo Kalabay ${ }^{3}$ and Peter Torzsa ${ }^{3 *}$ (i)
}

\begin{abstract}
Background: Burnout is increasingly prevalent among general practitioners (GPs) in Hungary, which may lead to functional impairment and, subsequently, to poor quality of patient care. However, little is known about potential predictors of burnout among GPs. The aim of this study was to explore psychosocial correlates of burnout among GPs and residents in Hungary.
\end{abstract}

Methods: We collected socio-demographic and work-related data with self-administered questionnaires in a cross-sectional study among GPS $(N=196)$ and residents $(N=154)$. We assessed burnout with the Maslach Burnout Inventory Human Services Survey (MBI-HSS) and calculated the mean level of burnout and the proportion of physicians suffering from low, intermediate and high degree of burnout. To identify potential socio-demographic and work-related correlates of burnout among physicians, we determined Spearman's and Mann-Whitney $U$ correlation coefficients and conducted stepwise linear regression analyses. We deployed Mann-Whitney $U$ test to explore gender disparity in the level of burnout between female and male physicians and between general practitioners and residents.

Results: The prevalence of moderate to high level emotional exhaustion, depersonalisation, and impaired personal accomplishment was 34.7, 33.5 and $67.8 \%$ as well as 41.0, 43.1, and 71.1\% among GPs and residents, respectively. Residents reported significantly lower level of personal accomplishment vs GPs. We identified a significantly higher level of depersonalization among male physicians compared to female physicians. Age correlated negatively with emotional exhaustion and depersonalization and positively with personal accomplishment among GPs. Dependant care was positively associated with burnout among female GPs. Female residents were more likely to report depersonalization. High workload was positively correlated with depersonalization among female GPs. Younger age emerged as the strongest predictor of emotional exhaustion. Male gender and fewer years of experience predicted depersonalization best, and male gender showed a significant predictive relationship with low personal accomplishment.

Conclusion: We identified specific socio-demographic and work-related correlates of burnout, which may guide the development of specific and effective organizational decisions to attenuate occupational stress and subsequent burnout as well as functional impairment among GPs, and thus, may improve the quality of patient care.

Keywords: Burnout, General practitioners, Residents, Gender, Correlates, Predictors

\footnotetext{
* Correspondence: torzsa.peter@med.semmelweis-univ.hu

${ }^{3}$ Department of Family Medicine, Medical Faculty, Semmelweis University,

Budapest, Hungary

Full list of author information is available at the end of the article
}

(c) The Author(s). 2018 Open Access This article is distributed under the terms of the Creative Commons Attribution 4.0 International License (http://creativecommons.org/licenses/by/4.0/), which permits unrestricted use, distribution, and reproduction in any medium, provided you give appropriate credit to the original author(s) and the source, provide a link to the Creative Commons license, and indicate if changes were made. The Creative Commons Public Domain Dedication waiver (http://creativecommons.org/publicdomain/zero/1.0/) applies to the data made available in this article, unless otherwise stated. 


\section{Background}

The well-being, defined as good mental and physical health, of general practitioners (GPs) is essential to maintaining an effective health care system as they are in the front line to guard and promote health, advocate and administer preventive care, diagnose new illnesses, and manage chronic ones.

However, research on the mental health of GPs in various countries has revealed high prevalence of distress, burnout, suicidal ideation, alcohol and substance misuse, anxiety, and depression [1-3], which have been associated with functional impairment and, subsequently, with poor quality of patient care [4, 5]. Furthermore, several studies demonstrated that the prevalence of burnout among residents ranges between 28.0 and $45.0 \%$ [6-8].

Burnout among GPs is of particular concern as there are many characteristics of contemporary general practice that increase the risk of burnout such as the high number of patient-doctor contacts, increased administrative burden, work stress due to high demands from patients and colleagues, reduced support from family and colleagues, as well as limited autonomy in decision-making [9-11]. Burnout is defined as a syndrome of emotional exhaustion, depersonalisation, and reduced personal accomplishment originally described by Maslach, Jackson, and Leiter [12], which develops as a response to chronic emotional or interpersonal distress.

Research in various countries has identified individual (e.g., behavioural, demographic, and personality-related), organisational, as well as societal determinants of burnout among physicians. For example, physicians often go to work even when they are ill [13] or make their own diagnoses and prescribe their own treatment [14]. Physicians rarely seek help for their ailments from other medical professionals and when they do so it is often after a long delay when their health condition has worsened [15]. Further individual risk factors are two personality types, neuroticism and perfectionism, which may play a significant role in the development of burnout through the deployment of maladaptive coping mechanisms for work stress [16]. Amongst demographic factors, age, dependant care demands such as large numbers of children and elderly people in the family requiring care, as well as gender have been identified as important determinants of burnout [17]. Whilst in the US burnout tends to occur most frequently among young employees [12], in Europe burnout seems to be more prevalent among older employees [18], which could be explained by limited workforce mobility in Europe. However, recent research in Europe has identified a trend of higher burnout levels among younger physicians compared to older ones [19].

The role of gender in the development of burnout has been extensively studied. While the results are inconclusive, in general, women score higher on emotional exhaustion, and men score higher on depersonalisation and personal accomplishment. This trend has also been described among physicians [20].

Amongst workplace characteristics, high job demands, role conflict, low job resources, and lack of workplace support have been identified as key risk factors of burnout among GPs and physicians [21-23]. Furthermore, our research among GPs in Hungary and studies in other European countries have shown that psychosocial stress affects the mental well-being of GPs and contributes to increased prevalence of burnout, anxiety, and depression [24-31].

In the Hungarian context, research consequently showed low personal accomplishment among nearly $100.0 \%$ of GPs and residents surveyed. Our previous study also revealed high level of depersonalisation and emotional exhaustion among 61.0 and $35.0 \%$ of the GPs, respectively. The proportion of Hungarian physicians with high levels of depersonalisation and low personal accomplishment is significantly higher than those obtained among Italian, Swiss, Spanish, and Canadian physicians [32].

Our research group has shown that in the Hungarian context, physician burnout is closely associated with workplace stress, and stress-related somatic diseases such as gastrointestinal and cardiovascular disorders [33]. Furthermore, in-depth interviews conducted among Hungarian physicians revealed that the causes of increased workplace stress were associated with reduced control over work (control over the amount of work and the number of patients), flaws of the organisational structure (poor communication, lack of cooperation, lack of support from more experienced physicians) and with stress resulting from unique work characteristics (e.g., high responsibility, failed attempts of treatment, long working hours). We also identified a further antecedent to workplace stress, namely work-family conflict, and found it as a strong correlate of burnout among female and male physicians in Hungary $[34,35]$. Our findings showed that the relative importance of the work domain in the development of work-family conflict within the Hungarian medical profession is more significant than that of the family domain. Because in Hungary men and women tend to adhere to traditional gender roles, female physicians need to cope with the supremacy of their work domain as a professional and with the significance of the family domain as a woman. These findings suggest that work and family-related factors are critically important in the pathogenesis of stress and stress-related morbidities including burnout and other somatic diseases among physicians in Hungary $[36,37]$. Whilst these relationships have been extensively studied among physicians, in general, little attention has been paid to identifying potential risk factors of burnout among GPs in particular. Given the pivotal role of GPs and residents in improving or maintaining 
public health, there is a strong rationale to explore psychosocial determinants and/or correlates of burnout among GPs and residents in Hungary. Based on transactional and interactional models of burnout as a theoretical framework $[38,39]$, the hypotheses of this research are as follows:

1. The prevalence of burnout among Hungarian GPs and residents is high.

2. Female GPs and residents experience significantly higher level of burnout compared to their male counterparts.

3. Older age is associated with burnout among GPs and residents.

4. High number of children (a surrogate of dependant care) is associated with burnout among female physicians.

5. High number of registered patients in the practice (a surrogate of workload) is associated with burnout among GPs and residents.

\section{Methods}

\section{Study design, setting, and participants}

We used a cross-sectional design and self-administered questionnaires, which we distributed to 346 general practitioners and 234 residents, who attended a Continued Medical Education (CME) course. Of the 580 participants, 350 general practitioners returned the appropriately completed questionnaire (196 general practitioners $(56.0 \%)$ and 154 residents (44.0\%)) and thus were selected for the study.

\section{Measures}

We used the Maslach Burnout Inventory Human Services Survey (MBI-HSS) [12]. This 22-item instrument has three subscales and measures (1) emotional exhaustion with 9 items, (2) depersonalization (alienation) from work, patients, and colleagues with 5 items, and (3) personal accomplishment which indicates job-related competency and subsequent self-esteem with 8 items. Responses are marked on a seven-point Likert scale (0 meaning 'never' and 6 meaning 'every day') and then summed. A high degree of burnout among general practitioners was reflected by sum scores of $\geq 27$ on the emotional exhaustion and $\geq 10$ on the depersonalization subscales, and a score of $\leq 33$ on the personal accomplishment subscale, which represent the cut-off scores at the upper tercile of the sample [12]. The reliability coefficients (Cronbach's alpha) of the emotional exhaustion, depersonalization, and personal accomplishment scales for our total sample were $0.9,0.8$, and 0.8 , respectively. Similar reliability coefficients on all subscales have been obtained for female and male physicians, and residents as well as GPs.

We collected sociodemographic data such as gender, age, number of children (as a surrogate of dependant care), and marital status. We also assessed workplace factors including type of practice (adult, paediatric, or mixed), number of patients in the practice (as a surrogate of workload) defined by the number of registered patients (social security cards) in the practice, years spent in the practice (as a surrogate of experience), and regular on-call duties over the week-end (at least once a month) as well as nightshift (defined as work hours between 7 PM and 7 AM the following day at least once a week).

\section{Data analyses}

We calculated mean scores and standard deviation (SD) for each of the three scales of burnout for the whole sample, for GPs and residents, as well as for female and male GPs. To explore differences in the mean scores of each burnout dimension between female and male physicians as well as general practitioners and residents, we deployed the Mann-Whitney U test.

We classified physicians into three groups based on the perceived level of burnout (high, intermediate, low) based on cut-off values reported by Maslach et al. [12]. To identify correlates of burnout among physicians, we assessed correlations among socio-demographic and workrelated characteristics (i.e., age, marital status, number of children, job title (GP or resident), number of patients in the practice, average of years spent in the practice, specialty focus (e.g., paediatrics, adults, mixed), and on-call duties over the week-end or nightshifts) and the three dimensions of burnout experienced by male and female physicians as well as the total sample by determining Spearman's $\left(r_{\mathrm{S}}\right)$ and Mann-Whitney U correlation coefficients for continuous and dichotomous dependent variables, respectively.

In order to explore the relationship between burnout and socio-demographic as well as work-related factors further, we conducted stepwise linear regression analyses and assessed the strength and direction of relationships between the continuous dependent variables (emotional exhaustion, depersonalization, personal accomplishment) and explanatory variables (age, gender, marital status, number of children, number of patients in the practice, average years spent in the practice, specialty, on-call over weekends, nightshifts, and job title (GP vs resident)) by determining regression coefficients (adjusted $\beta$ ), 95\% confidence intervals $(95 \% \mathrm{CI})$, and $\mathrm{t}$-test statistics. We used $\mathrm{F}$ statistics to confirm the significance of models at each step. We controlled for gender and type of employment (inpatient/outpatient services, general practice, and other establishments) in the analyses. In addition, we calculated the proportion of the variance in the dependent variable explained by the explanatory variables (adjusted $\mathrm{R}^{2}$ ). One model for emotional exhaustion, two for depersonalization and one for personal accomplishment have been examined. The models were significant for each step as determined by $\mathrm{F}$ statistics (data not shown). A $p$ value of $<0.05$ was considered as 
statistically significant. The statistical software used for all analyses was SPSS, version 20.0 (IBM-SPSS Inc., Armonk, NY, USA).

\section{Results}

\section{Participant characteristics}

The overall response rate was $60.3 \%$. Table 1 shows the demographic profile of the sample. The average age (SD) was 45.6 years (15.0) (age ranging from 25 to 79 years). Most of the physicians were partnered (78.2\%) and had children (67.1\%). The average number of patients in the practice was similar among male and female physicians. The average (SD) of years spent in the practice was 12.0
(12.7) years. Only around one fifth and one third of the female and male physicians, respectively, took on-call duty over the week-end and night-shift (Table 1). GPs and residents in our sample represent $3.0 \%$ of the total number of GPs (6541) and 66.0\% of residents (234) in Hungary, respectively. In the normative population, the proportion of female GPs is $68.0 \%$ and most GPs are in the 50-59-year-old cohort. The distribution of GPs among adult, paediatric, and mixed practices is 54.0, 23.0, and $23.0 \%$ in Hungary. Our study sample may be representative of the normative population in terms of gender, age distribution, residents, and GPs focusing on adult patients.

Table 1 Sociodemographic characteristics of the sample

\begin{tabular}{|c|c|c|c|}
\hline Variable & $\begin{array}{l}\text { Total sample } \\
\text { N (\%) }\end{array}$ & $\begin{array}{l}\text { Female }^{a} \\
\mathrm{~N}(\%)\end{array}$ & $\begin{array}{l}\text { Male }^{a} \\
N(\%)\end{array}$ \\
\hline Total sample & $350(100.0)$ & $209(59.7)$ & $141(40.3)$ \\
\hline General practitioners & $196(56.0)$ & $108(51.7)$ & $88(32.4)$ \\
\hline Residents & $154(44.0)$ & $101(48.3)$ & $53(37.6)$ \\
\hline \multicolumn{4}{|l|}{ Age group (years) } \\
\hline$<30$ & $88(25.3)$ & $58(28.0)$ & $30(21.3)$ \\
\hline $30-39$ & $53(15.2)$ & $34(16.4)$ & $19(13.4)$ \\
\hline $40-49$ & $50(14.4)$ & $30(14.5)$ & $20(14.2)$ \\
\hline $50-59$ & $80(23.0)$ & $42(20.3)$ & $38(27.0)$ \\
\hline$\geq 60$ & $77(22.1)$ & $43(20.8)$ & $34(24.1)$ \\
\hline \multicolumn{4}{|l|}{ Partner } \\
\hline Yes & $248(78.2)$ & $134(73.2)$ & $114(85.1)$ \\
\hline No & $69(21.8)$ & $49(26.8)$ & $20(14.9)$ \\
\hline \multicolumn{4}{|l|}{ Number of children } \\
\hline None & $114(32.9)$ & $71(34.0)$ & $43(31.2)$ \\
\hline Yes & $233(67.1)$ & $138(66.0)$ & $95(68.8)$ \\
\hline 1 & $56(24.0)$ & $36(26.1)$ & $20(21.1)$ \\
\hline 2 & $105(45.1)$ & $69(50.0)$ & $36(37.9)$ \\
\hline$\geq 3$ & $72(30.9)$ & 33 (23.9) & $39(41.0)$ \\
\hline $\begin{array}{l}\text { Number of registered patients in GP practice } \\
\text { (Mean (SD)) }\end{array}$ & $1813.9(534.2)$ & 1738.9 (546.6) & $1900.9(508.7)$ \\
\hline \multicolumn{4}{|l|}{ Type of GP practice } \\
\hline Adult & $291(72.9)$ & $155(74.2)$ & $113(80.1)$ \\
\hline Paediatric & $32(8.0)$ & $28(13.4)$ & $4(2.8)$ \\
\hline Mixed & $43(10.8)$ & $19(9.1)$ & 139 (98.6) \\
\hline Missing data & $33(8.3)$ & $7(3.3)$ & $2(1.4)$ \\
\hline $\begin{array}{l}\text { Average years in GP practice } \\
\text { (Mean (SD)) }\end{array}$ & $12.0(12.7)$ & $11.9(12.5)$ & $14.1(13.3)$ \\
\hline \multicolumn{4}{|l|}{ On-call over week-end, nightshift } \\
\hline No & $143(73.0)$ & $86(81.1)$ & $57(64.8)$ \\
\hline Yes & $51(26.0)$ & $20(18.9)$ & $31(35.2)$ \\
\hline Missing data & $2(1.0)$ & & \\
\hline
\end{tabular}

${ }^{\mathrm{a} G e n e r a l ~ p r a c t i t i o n e r s ~ a n d ~ r e s i d e n t s ~ c o m b i n e d ~}$ 
High prevalence of burnout among general practitioners and residents

In line with our first hypothesis, a sizeable proportion of GPs and resident reported high level of burnout. Among GPs, 19.9, 18.0, and 45.9\% reported high level of emotional exhaustion, depersonalization, and impaired personal accomplishment, respectively. The prevalence of high level of emotional exhaustion, depersonalization, and impaired personal accomplishment among residents was similar (18.5, 25.5, and 39.5\%, respectively). Moderate to high levels of emotional exhaustion and depersonalization were reported by 34.7 and $33.5 \%$ as well as by 41.0 and $43.1 \%$ of GPs and residents, respectively. Moderate to high level impaired personal accomplishment was also prevalent among GPs and residents $(67.8$ and $71.1 \%$, respectively) (Table 2).

Whilst we observed no significant differences in the level of emotional exhaustion and depersonalization between GPs and residents, residents reported significantly lower level of personal accomplishment compared to GPs (Mann-Whitney $U=12,247.0 ; p<0.01$ ) (Table 2).

\section{Gender disparity in the level of depersonalization between female and male physicians}

In contrary to our second hypothesis, our results demonstrated a significantly higher level of depersonalization among male physicians compared to female physicians (Mann-Whitney $U=12,221.0 ; p<0.01$ ). We found no significant gender differences in the levels of emotional exhaustion and personal accomplishment (Table 3).

\section{Socio-demographic and work-related correlates of burnout among GPs and residents}

As demonstrated in Table 4, we identified that age negatively correlated with both emotional exhaustion and depersonalization among female physicians $\left(r_{\mathrm{S}}=-0.193\right.$, $\left.p<0.01 ; \mathrm{r}_{\mathrm{S}}=-0.220, p<0.001\right)$, male physicians $\left(\mathrm{r}_{\mathrm{S}}=-\right.$ $\left.0.206, p<0.01 ; \mathrm{r}_{\mathrm{S}}=-0.191, p<0.05\right)$, and in the total sample $\left(r_{S}=-0.186, p<0.01 ; r_{S}=-0.198, p<0.001\right)$, respectively. Age correlated positively with personal accomplishment among female physicians $\left(\mathrm{r}_{\mathrm{S}}=0.358\right.$, $p<0.001)$ and the total sample $\left(\mathrm{r}_{\mathrm{S}}=0.234, p<0.001\right)$ but not among male physicians. These results are contrary to our third hypothesis, which stipulated that age was a potential positive correlate of burnout among GPs and residents.

In line with our fourth hypothesis, we found that the number of children (a surrogate of dependant care) was a significant positive correlate of emotional exhaustion $\left(\mathrm{r}_{\mathrm{S}}=0.159 ; p<0.05\right)$ and depersonalization $\left(\mathrm{r}_{\mathrm{S}}=0.141\right.$, $p<0.05)$, and a negative correlate of personal accomplishment $\left(\mathrm{r}_{\mathrm{S}}=-0.178, p<0.01\right)$ among female physicians. In addition, the number of children had a positive association with emotional exhaustion $\left(r_{\mathrm{S}}=0.119, p<0.05\right)$ and depersonalization $\left(\mathrm{r}_{\mathrm{S}}=0.117, p>0.05\right)$ in the total sample (Table 4).

Our results showed that among female physicians, being a resident was significantly correlated with depersonalisation (mean ranks were 112.9 vs 95.7 among residents vs GPs, respectively, Mann-Whitney $\mathrm{U}=4461.5, p<0.05$ ) and being a general practitioner was significantly correlated with personal accomplishment (mean ranks were 118.1 vs 88.6 among GPs vs residents, respectively, Mann-Whitney $\mathrm{U}=3823.5, p<0.001)$. In addition, being a GP was a significant positive correlate of personal accomplishment in the total population (mean ranks were 188.0 vs 157.0 among GPs vs residents, respectively, Mann-Whitney $U=12,247.0$, $p<0.01$ ) (Table 4).

We found that the number of registered patients in the practice (a surrogate of workload) was significantly associated with depersonalization $\left(\mathrm{r}_{\mathrm{S}}=0.216, p<0.05\right)$ among female physicians. These results confirm, at least in part, our final hypothesis, as we could demonstrate associations between the number of patients in the practice and burnout, albeit only for one burnout dimension (depersonalization) and among female physicians only. Furthermore, the average of years spent in the practice (a surrogate of experience) was a significant inverse correlate of depersonalization among female physicians $\left(\mathrm{r}_{\mathrm{S}}=-\right.$ 0.176, $p<0.01)$ and the total sample $\left(\mathrm{r}_{\mathrm{S}}=-0.133, p<0.01\right)$ and a positive correlate of personal accomplishment among female physicians $\left(\mathrm{r}_{\mathrm{S}}=0.264, p<0.001\right)$ and in the total sample $\left(\mathrm{r}_{\mathrm{S}}=0.168, p<0.01\right)$. We did not find significant correlations between burnout and a few other sociodemographic and work-related variables such as marital status, specialty focus (i.e., paediatric or adult patients

Table 2 Prevalence of burnout among general practitioners $(N=196)$ and residents $(N=154)$

\begin{tabular}{|c|c|c|c|c|c|c|c|}
\hline \multirow[t]{2}{*}{ Variable } & \multicolumn{2}{|l|}{ High level } & \multicolumn{2}{|c|}{ Moderate level } & \multicolumn{2}{|l|}{ Low level } & \multirow[t]{2}{*}{ Mann-Whitney U-test } \\
\hline & GPs & Residents & GPs & Residents & GPs & Residents & \\
\hline \multicolumn{8}{|l|}{ Burnout N (\%) } \\
\hline Emotional exhaustion & 39 (19.9) & $28(18.5)$ & $29(14.8)$ & $34(22.5)$ & $128(65.3)$ & $89(58.9)$ & $N S^{a}$ \\
\hline Depersonalization & $35(18.0)$ & 39 (25.5) & $30(15.5)$ & $27(17.6)$ & $129(65.5)$ & $87(56.9)$ & $N S^{a}$ \\
\hline Impaired personal accomplishment & $90(45.9)$ & $60(39.5)$ & $43(21.9)$ & 48 (31.6) & $63(32.1)$ & $44(28.9)$ & $U=12,247.0^{* *}$ \\
\hline
\end{tabular}


Table 3 Gender differences in the level of burnout among female $(N=209)$ and male $(N=141)$ physicians

\begin{tabular}{|c|c|c|c|}
\hline Burnout & $\begin{array}{l}\text { Female } \\
\text { physicians }\end{array}$ & $\begin{array}{l}\text { Male } \\
\text { physicians }\end{array}$ & $\begin{array}{l}\text { Mann-Whitney } \\
\text { U-test }\end{array}$ \\
\hline $\begin{array}{l}\text { Emotional exhaustion } \\
\text { Mean Rank }\end{array}$ & 170.4 & 179.4 & $N S^{a}$ \\
\hline $\begin{array}{l}\text { Depersonalization } \\
\text { Mean Rank }\end{array}$ & 163.0 & 190.2 & $U=12,221.0^{* *}$ \\
\hline $\begin{array}{l}\text { Personal accomplishment } \\
\text { Mean Rank }\end{array}$ & 177.7 & 169.7 & $N S^{a}$ \\
\hline
\end{tabular}

${ }^{a}$ NS Not significant

${ }^{* *} p<0.01$

or a combination thereof), and on-call duties over the week-end or nightshifts (Table 4).

The results of our regression analyses showed that of the variables examined (age, gender, marital status, number of children, number of patients in the practice, average years spent in the practice, specialty, on-call over week-ends, nightshifts, and job title (GP vs resident)), younger age $(\beta=-0.153,95 \%$ CI $-0.343--0.01)$ predicted emotional exhaustion best. Male gender $(\beta=-0.211,95 \%$ CI -3.974 - -0.788) and fewer years spent in practices ( $\beta=-0.156,95 \%$ CI $-0.156--0.008)$ emerged as best predictors of depersonalization. Low personal accomplishment was best predicted by male gender $(\beta=0.177$, 95\% CI 0.541-5.139). These predictors explained 2.3, 2.4 , and $3.1 \%$ of the variance in emotional exhaustion, depersonalization and low personal accomplishment, respectively (Table 5).

\section{Discussion}

In this study, we found high prevalence of burnout and significant gender disparity among Hungarian GPs and residents. Residents reported significantly higher level of burnout (low level of personal accomplishment) vs GPs. In addition, we determined various psychosocial correlates of burnout and identified younger age, male gender, and fewer years of experience as significant predictors of specific burnout dimensions among the physicians.

The primary goal of our study was to assess the prevalence of burnout in a sample of GPs and residents in Hungary. In line with our first hypothesis, our results suggest that burnout is relatively prevalent in this population, with $18.0-25.5 \%$ reporting a high level of emotional exhaustion and depersonalization, and 39.5-45.9\% of the sample reporting a high level of impaired personal accomplishment. The comparison of our findings with the results from studies of burnout among Italian [40], UK [41], European [42], Irish [43], Canadian [44], and Slovenian [45] GPs revealed that Hungarian GPs reported comparatively lower levels of emotional exhaustion and depersonalization, but significantly higher level of impaired personal accomplishment. Our findings about the high prevalence of impaired personal accomplishment among
GPs and residents are in line with the results of our research among physicians in Hungary. We posit that low level of personal accomplishment could develop independently and in parallel with exhaustion [46]. This may be observed in certain organisational environments characterised by role conflict or work overload that on the one hand intensify emotional exhaustion and on the other hand simultaneously reduce personal accomplishment through disabling participative decision making and social support, which serve as significant facilitators of personal accomplishment [35]. Our results support the growing body of evidence which has found increasing prevalence of burnout among GPs all over the world.

Another objective of our study was to identify correlates (or potential predictors) of burnout among GPs and residents in Hungary focusing on socio-demographic and work-related factors. Based on a multitude of evidence, it is generally suggested that female employees may be more susceptible to experiencing burnout. In particular, data suggest that women may be more prone to experiencing a greater level of emotional exhaustion than men and that men more frequently report depersonalization than women. Our results confirm these findings. Whilst we found a significantly higher mean level of depersonalization among male GPs, we did not see a difference in emotional exhaustion. In addition, our results suggest that male GPs and residents might be more likely to report depersonalization and reduced personal accomplishment than women. However, data in the literature appear to be inconclusive regarding the strength and direction of gender differences in burnout and only a handful of authors have explored this relationship directly. In a recent meta-analysis of the relationship between gender and burnout, results demonstrated that women were slightly more emotionally exhausted than men, while men are somewhat more depersonalized than women [47]. In line with our hypothesis, our results confirm, at least in part, these findings. Our findings underpin the significance of gender research regarding burnout because they would contribute to making adequate and accurate organizational decisions to reduce occupational stress and consequent burnout.

Of all the demographic variables, age has been extensively studied and most consistently related to burnout [48]. Several studies have suggested that younger employees experience higher level of burnout than older ones. Age is associated with work experience, and it has been postulated that younger employees have less work experience, which may lead to higher level of occupational stress and subsequent burnout. Indeed, research has shown a decrease in the burnout scores of all three dimensions as the subjects' age increased [49]. However, others have found no significant differences in burnout among different age ranges [50]. In contrary to our third 


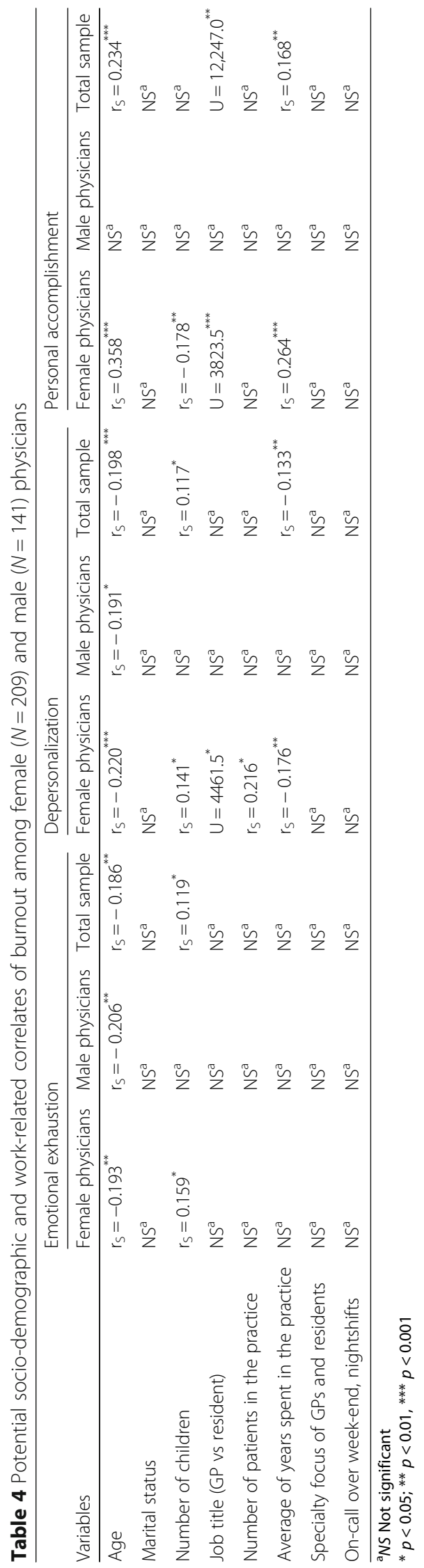


Table 5 Potential predictors associated with burnout (emotional exhaustion, depersonalization and reduced personal accomplishment) among general practitioners and residents: stepwise linear regression analyses

\begin{tabular}{llllll}
\hline Dependent variables & Independent variables & Standardized $\beta$ & $95 \%$ Confidence intervals & $t$ & Adjusted R \\
\hline Emotional exhaustion & Age (younger) & -0.153 & $-0.343--0.010$ & $-2.096^{*}$ & 0.023 \\
Depersonalization & Gender (male) & -0.211 & $-3.974--0.788$ & $-2.949^{* *}$ & 0.024 \\
& Average years spent in practice (shorter) & -0.156 & $-0.156--0.008$ & $-2.174^{*}$ \\
Personal accomplishment & Gender (female) & 0.177 & $0.541-5.139$ & $2.438^{*}$ & 0.031 \\
\hline
\end{tabular}

${ }^{*} p<0.05,{ }^{* *} p<0.01$

hypothesis, our results showed that older age and time spent in the practice (a surrogate of experience) were inversely correlated with emotional exhaustion and depersonalization, and positively correlated with personal accomplishment among GPs and residents. Furthermore, regression analyses suggested a predictive role for age and time spent in practice (a surrogate of experience) in reducing emotional exhaustion and depersonalization among GPs, respectively. Our findings therefore support the line of evidence that stipulates a significant association between age as well as age-related experience and burnout. However, our findings should be interpreted with caution because of the potential issue of survival bias, i.e. those who burn out early in their careers are likely to quit their jobs, leaving behind the survivors who consequently exhibit lower levels of burnout. A meta-analysis conducted by Brewer and Shapard [51] showed a weak but significant negative correlation between employee age and emotional exhaustion. Based on these results and our findings, we suggest that age should be included in the risk profile for GPs.

In terms of our fourth hypothesis, we found evidence that a higher number of children (a surrogate of dependant care) was a significant correlate of burnout among female physicians. Our findings provide empirical support for the line of evidence, which suggests that dependant care (e.g., child rearing, looking after old parents) provided by working women is a source of chronic stress and ensuing burnout [11]. A plausible explanation for our findings could be that Hungarian female GPs may experience work-family conflict, a type of distress, which arises from the inability to balance the demands at work and at home. This could be due to the lack of efficient family-friendly policies in the Hungarian medical profession and the typically long working hours, which make combining work and family roles difficult for female physicians and particularly to physician mothers. Thus, female physicians in Hungary often find themselves compelled to fulfil a number of roles (mother, spouse, doctor) to the highest standards concurrently. This leads to work-family conflict and subsequently to burnout [35].

Our results confirm our fifth hypothesis, which stated that the number of patients in the practice (a surrogate of workload) positively correlated with of burnout. In particular, we identified this relationship for depersonalization among female physicians. There is a large body of evidence which shows that workload is a significant risk factor of burnout [12]. Work overload or high work demands, especially when occurs with lack of control and support, has been shown to predict emotional exhaustion, a central component of burnout [8]. On the other hand, lack of job resources has been theorized to account for depersonalization or disengagement [39] dimension of burnout. There is evidence to suggest that both of these processes occur at the same time. Based on our results, we posit that emotional exhaustion caused by work overload may augment disengagement and depersonalization, which is further corroborated by the lack of job resources among female GPs such as organizational policies to help balance work and home domain activities in a traditional society where female physicians are expected to fulfil multiple roles. This hypothesis would fit Leiter's model of burnout, which states that emotional exhaustion leads to depersonalization and cynical attitudes toward work as employees attempt to remove themselves emotionally from their job as a way of coping with stress [46].

Our study has some limitations such as its cross-sectional nature, which includes biases of self-reporting and the inability to confer causality. In addition, our study sample might only be representative of GPs working in adult practices but not of GPs in paediatric and mixed practices. Also, whilst the response rate was high, non-responders might have biased the results as they might not suffer from burnout, hence burnout levels in the study might have been overestimated. Furthermore, we used arbitrary cut-off scores to classify general practitioners into cohorts reporting high, intermediate and low levels of burnout on the three dimensions. Whilst this method is useful to explore the objectives of the study in the research setting, it cannot be directly extrapolated into the clinical setting to support diagnosis of burnout.

Despite the limitations, our study has important strengths and significance for the practice. First of all, it is one of the first studies to explore psychosocial correlates and/or predictors of burnout among GPs in Hungary, plagued with severe shortage of physicians in almost every large specialty, and a rapidly ageing GP population. Furthermore, our study is one of the few investigations that explore the prevalence and potential predictors of burnout among residents [52]. 
In line with this line of research, our results confirm the multicausal nature of burnout among medical residents. In addition, our study provides a base for further explorations by virtue of generating hypotheses and developing research strategies for deploying effective interventions. In particular, recent research on the applicability of the MBI scales for supporting the diagnosis and management of burnout in the clinical setting based on a multi-dimensional model (a combination of the highest reported score on one of the three dimensions of burnout and various degrees of burnout reported on the remaining two scales) has suggested the development of five burnout profiles such as 'engaged', 'ineffective,' 'overextended,' 'disengaged', and 'burnout' [53]. Our results, in combination with our previous research, suggest that Hungarian GPs may fall into the 'ineffective' profile, which is characterised by low scores on the personal accomplishment scale as the leading burnout dimension. One of the objectives of these burnout profiles is to aid the development of appropriate interventions. Based on our results and those of others about the specific predictors of various burnout dimensions, we suggest that GPs with an 'ineffective' profile would benefit more from interventions that address resources, social support, and job satisfaction than from interventions that focus on reducing work overload or strengthening values, which have been associated with the 'overextended' and 'disengaged' burnout profiles, respectively.

\section{Conclusions}

Our study provides insights into the potential genderspecific and psychosocial correlates of the different burnout dimensions among GPs and residents in Hungary and thus sets forth future directions not only for further gender, cross-cultural, and occupational research but also for specific interventions and preventive measures to reduce physician burnout and subsequent physician impairment and, thus, to improve retention and recruitment of GPs, and ultimately the quality of primary care.

\author{
Abbreviations \\ CME: Continued Medical Education; GP: General Practitioner; MBI-HSS: Maslach \\ Burnout Inventory

\section{Acknowledgements} \\ Not Applicable

\section{Ethcs approval and consent to participate} \\ Semmelweis University Regional and Institutional Committee of Science and \\ Research Ethics TUKEB number: 26/2012. \\ Address: Budapest, Üllői út 93., 1091.

\section{Funding} \\ The authors declare that they they did not have any funding for this research.
}

\section{Availability of data and materials}

The questionnaires and data for this study is currently available at the Department of Family Medicine, Semmelweis University. We do not want to share our data because we are planning to write another paper from our database.

\section{Authors' contributions}

SZA analysed the data, wrote the manuscript, co-ordinated the study. AM analysed and collected the data, contributed to the manuscript (results). LK contributed to the whole study concept, the study design and to sections of the manuscript (discussion, methods). PT participated in the interpretation of the data, and the drafting of the manuscript.He gave the final approvel of the version to be published. All authors have read and approved the final version of this manuscript.

Consent for publication

Not applicable

\section{Competing interests}

The authors declare that they have no competing interests.

\section{Publisher's Note}

Springer Nature remains neutral with regard to jurisdictional claims in published maps and institutional affiliations.

\section{Author details}

${ }^{1}$ Institute of Behavioural Sciences, Semmelweis University, Budapest, Hungary. ${ }^{2}$ Department of Family Medicine, Faculty of Medicine, University of Szeged, Szeged, Hungary. ${ }^{3}$ Department of Family Medicine, Medical Faculty, Semmelweis University, Budapest, Hungary.

Received: 13 September 2018 Accepted: 29 November 2018 Published online: 12 December 2018

\section{References}

1. Shanafelt TD, Boone S, Tan L, Dyrbye LN, Sotile W, Satele D, et al. Burnout and satisfaction with work-life balance among US physicians relative to the general US population. Arch Intern Med. 2012;172(18):1377-85.

2. Firth-Cozens J. Depression in doctors. In: Robertson MM, Katona CLE, editors. Depression and physical illness. New York: John Wiley; 1997. p. 95-111.

3. Schernhammer ES, Colditz GA. Suicide rates among physicians: a quantitative and gender assessment (meta-analysis). Am J Psychiatr. 2004;161:2295-302

4. Dewa CS, Loong D, Bonato S, Trojanowski L. The relationship between physician burnout and quality of healthcare in terms of safety and acceptability: a systematic review. BMJ Open. 2017;7(6):e015141 Published 2017 Jun 21.

5. Shanafelt TD, Bradley KA, Wipf JE, Back AL. Burnout and self-reported patient care in an internal medicine residency program. Ann Intern Med. 2002;136:358-67.

6. Dyrbye LN, Thomas MR, Huntington JL, Lawson KL, Novotny PJ, Sloan JA. Personal life events and medical student burnout: a multicentre study. Acad Med. 2006;81:374-84.

7. Willcock SM, Daly MG, Tennant CC, Allard BJ. Burnout and psychiatric morbidity in new medical graduates. Med J Aust. 2004;181:357-60.

8. Soler JK, Yaman H, Esteva M, Dobbs F. Burnout in European family doctors: the EGPRN study. Fam Pract. 2008;1:1-21.

9. Bakker A, Schaufeli WB, Sixma HJ, Bosveld W, Van Dierendonck D. Patient demands, lack of reciprocity, and burnout: a five-year longitudinal study among general practitioners. J Organ Behav. 2000;21(4):425-41.

10. Shirom A, Nirel N, Vinokur AD. Overload, autonomy, and burnout as predictors of physicians' quality of care. J Occup Health Psychol. 2006;11(4): 328-42.

11. Spickard A Jr, Gabbe SG, Christensen JF. Mid-career burnout in generalist and specialist physicians. JAMA. 2002;288(12):1447-50.

12. Maslach C, Jackson SE, Leiter MP. Maslach burnout inventory manual. 3rd ed. Palo Alto, CA: Consulting Psychologists Press; 1996.

13. Johns G. Presenteeism in the workplace: a review and research agenda. J Organ Behav. 2010;31:519-42.

14. Montgomery AJ, Bradley C, Rochfort A, Panagopoulou E. A review of selfmedication in physicians and medical students. Occup Med Lond. 2011;61: 490-7.

15. Fridner A, Belkić K, Marini M, Gustafsson Sendén M, Schenck-Gustafsson K. Why don't academic physicians seek needed professional help for psychological distress? Swiss Med Wkly. 2012;142:1362-6. 
16. SwiderRyan BW, Zimmerman D. Born to burnout: a meta-analytic path model of personality, job burnout, and work outcomes. J Vocat Behav. 2010;76:487-506.

17. Kinnunen U, Mauno S. Antecedents and outcomes of work-family conflict among employed women and men in Finland. Hum Relat. 1998;51(2):157-77.

18. Schaufeli WB, VanDierendonck D. Handleiding van de Utrechtse Burnout Schaal (UBOS) [Manual Utrecht Burnout Scale]. Lisse: Swets \& Zeitlinger; 2000.

19. Løvseth LT, Fridner A, Jónsdóttir LS, Marini M, Linaker OM. Associations between confidentiality requirements, support seeking and burnout among university hospital physicians in Norway, Sweden, Iceland and Italy (the HOUPE study). Stress Health. 2013;29:432-7.

20. Linzer M, McMurray JE, Visser MR, Oort FJ, Smets E, Haes HC. Sex differences in physician burnout in the United States and the Netherlands. J Am Med Wom Assoc. 2002;57(4):191-3.

21. Lee RL, Ashforth BE. A meta-analytic examination of the correlates of the three dimensions of job burnout. J Appl Psychol. 1996;81(2):123-33.

22. Grassi L, Magnani K. Psychiatric morbidity and burnout in the medical profession: an Italian study of general practitioners and hospital physicians. Psychother Psychosom. 2003;69:329-34.

23. Robinson GE. Stresses on women physicians: consequences and coping techniques. Depression and Anxiety. 2003;17:180-9.

24. Cooper CL, Rout U, Faragher B. Mental health, job satisfaction, and job stress among general practitioners. Br Med J. 1989;298:366-70.

25. Caplan RP. Stress, anxiety, and depression in hospital consultants, general practitioners, and senior health service managers. Br Med J. 1994;309:1261-3.

26. Chambers R, Campbell I. Anxiety and depression in general practitioners: associations with type of practice, fund holding, gender and other personal characteristics. Fam Pract. 1996;13:170-3.

27. Appleton K, House A. Dowell a. a survey of job satisfaction, sources of stress and psychological symptoms among general practitioners in Leeds. Br J Gen Pract. 1998;428:1059-63.

28. Sobrequés Soriano J, Cebrià J, Segura J, Rodríguez C, García M, Juncosa S. Job satisfaction and burnout in general practitioners. Aten Primaria. 2003;31:227-33.

29. Kirwan $M$, Armstrong D. Investigation of burnout in a sample of British general practitioners. Br J Gen Pract. 1995;394:259-60.

30. Vićentić S, Jovanović A, Dunjić B, Pavlović Z, Nenadović M, Nenadović N. Professional stress in general practitioners and psychiatrists - the level of psychological distress and burnout risk. Vojnosanit Pregl. 2010;67:741-6.

31. Vörös K, Torzsa P, Kalabay L. Burnout a napi praxisban. [Burnout in daily practice]. Magyar Családorvosok Lapja. 2008;10:22-6.

32. Sz Á, Torzsa P, Zs G, Vörös K, Kalabay L. Gyakori a magas fokú kiégés a háziorvosok és háziorvosi rezidensek körében. [Frequent occurance of high level burnout among general practitioners and residents]. Orv Hetil. 2009;150(7):317-23.

33. Ádám S, Mészáros V. A humán szolgáltató szektorban dolgozók kiégésének mérésére szolgáló Maslach Kiégés Leltár magyar változatának pszichometriai jellemzői és egészségügyi korrelátumai orvosok körében. [Psychometric properties and health correlates of the Hungarian version of the Maslach Burnout Inventory - Human Services Survey (MBI-HSS) among physicians]. Mentálhig Pszichoszomatika. 2012;13(2):127-43.

34. Győrffy Z, Ádám S. Az egészségi állapot, a munkastressz és a kiégés alakulása az orvosi hivatásban. [Health status, work stress and burnout among physicians]. Szociológiai Szemle. 2004;3:107-217.

35. Ádám S, Győrffy Z, Susánszky É. Physician burnout in Hungary: a potential role for work-family conflict. J Health Psychol. 2008;13(7):847-56.

36. Ádám S. Magas a munkahelyi és a családi szerepek közötti konfliktus prevalenciája az orvosnők körében: a társas támogatás hiánya, mint lehetséges rizikótényező. [High prevalence of work-family conflict among female physicians: lack of social support as a potential antecedent.] Orv Hetil 2009; 150(50):2274-2281.

37. Ádám S. Work-family conflict among female and male physicians in Hungary: prevalence, stressors, predictors and potential consequences on physician's well-being. Budapest: PÁLÚR Kft; 2013. p. 67-74.

38. Leiter MP, Maslach C. A mediation model of job burnout. In: Antoniou ASG, Cooper $\mathrm{CL}$, editors. Research companion to organizational health psychology. Cheltenham: Edward Elgar; 2005.

39. Demerouti E, Bakker AB, Nachreiner F, Schaufeli WB. The job demandsresources model of burnout. J. Appl. Psychol. 2001;86(3):499-512.
40. Grassi L, Magnani K. Psychiatric morbidity and burnout in the medical profession: an Italian study of general practitioners and hospital physicians. Psychother Psychosom. 2000;69:329-34.

41. Orton P, Orton C, Gray DP. Depersonalised doctors: a cross-sectional study of 564 doctors, 760 consultations and 1876 patient reports in UK general practice. BMJ Open. 2012;2:e000274.

42. Soler JK, Yaman H, Esteva M, Dobbs F. European general practice research network burnout study group. Burnout in European family doctors: the EGPRN study. Fam Pract. 2008;25:245-65.

43. O'Dea B, O'Connor P, Lydon S, Murphy AW. Prevalence of burnout among Irish general practitioners: a cross-sectional study. Ir J Med Sci. 2017;186:447.

44. Lee FJ, Stewart M, Brown JB. Stress, burnout, and strategies for reducing them: what's the situation among Canadian family physicians? Can Fam Physician. 2008:54:234-5.

45. Penšek L, Selič P. Empathy and burnout in Slovenian family medicine doctors: the first presentation of Jefferson scale of empathy results. $Z d r$ Varst. 2018;57(3):155-65.

46. Leiter MP. Burnout as a developmental process: consideration of models. In: Schaufeli WB, Maslach C, Marek T, editors. Professional burnout: recent developments in theory and research. Washington, DC: Taylor \& Frances; 1993. p. 237-50

47. Purvanova RK, Muros JP. Gender differences in burnout: a meta-analysis J Vocat Behav. 2010;77(2):168-85

48. Maslach C, Schaufeli WB, Leiter MP. Job burnout. Annu Rev Psychol. 2001;52:397-422.

49. Akkus $Y$, Karacan $Y$, Göker $H$, Aksu S. Determination of burnout levels of nurses working in stem cell transplantation units in Turkey. Nurs Health Sci. 2010;12:444-9.

50. Kiekkas P, Spyratos F, Lampa E, Aretha D, Sakellaropoulos GC. Level and correlates of burnout among orthopaedic nurses in Greece. Orthop Nurs. 2010;29:203-9.

51. Brewer EW, Shapard L. Employee burnout: a meta-analysis of the relationship between age or years of experience. Hum Resour Dev Rev. 2004;3(2):102-23.

52. Prins JT, Gazendam-Donofrio SM, Tubben BJ, van der Heijden FMMA, De Wiel HBMV, Hoekstra-Weebers JEHM. Burnout in medical residents: a review. Med Educ. 2007:41(8):788-800

53. Leiter MP, Maslach C. Latent burnout profiles: a new approach to understanding the burnout experience. Burnout Research. 2016;3(4):89-100.

\section{Ready to submit your research? Choose BMC and benefit from:}

- fast, convenient online submission

- thorough peer review by experienced researchers in your field

- rapid publication on acceptance

- support for research data, including large and complex data types

- gold Open Access which fosters wider collaboration and increased citations

- maximum visibility for your research: over $100 \mathrm{M}$ website views per year

At $\mathrm{BMC}$, research is always in progress.

Learn more biomedcentral.com/submission 